17. Сахарова А.С., Якупов Н.А. Красивоцветущие деревья и кустарники для зеленого строительства Башкирии // Дикорастущие и интродуцируемые полезные растения в Башкирии (вып. 2). Казань: Изд-во Казанского ун-та, 1968. С. 231-269.
18. Полякова Н.В., Путенихин В.П., Вафин Р.В. Сирени в Башкирском Предуралье: интродукция и биологические особенности. Уфа: Гилем, 2010. 170 с.

19. Методика фенологических наблюдений в ботанических садах СССР. М., 1975.78 с.

\title{
SPECIES AND SORTS OF LILAC FLOWERING DURATION IN UFA
}

(C) 2018

Polyakova Natalia Viktorovna, candidate of biological sciences,

senior researcher of Dendrology, Forest Tree Breeding and Introduction of Woody Plants Laboratory

South-Ural Botanical Garden-Institute of the Ufa Federal Research Centre of Russian Academy of Sciences

(Ufa, Russian Federation)

\begin{abstract}
The paper presents characteristics of lilac flowering duration in the South-Ural Botanical GardenInstitute of Ufa Federal Research Center of the Russian Academy of Sciences. When selecting prospective species and sorts for landscaping purposes for each region, it is necessary to obtain a comprehensive assessment of decorative features. Lilac is now widely used in green building and is one of the most popular ornamental shrubs. The duration of flowering is one of the most important characteristics of ornamental plants and determines the decorative effect of the entire landscape composition. The paper presents the study results of the flowering duration of 11 species and 33 sorts of lilacs of the botanical garden collection for the last 7 years (2011-2017). The results obtained are shown in comparison with the data of earlier studies (2005-2009). The data analysis showed that in 2011-2017 the average lilac species flowering duration was 7-15, and that of varieties 13-15 days, which is 5-6 days shorter than the flowering period of the same taxa in 2005-2009. It is established that such a result is a consequence of changes in the climatic situation in the region. The obtained data on the lilac species flowering duration in Ufa, as well as the influence of climatic conditions on it, make it possible to successfully apply the studied species and varieties of lilacs for landscape design purposes in the Republic of Bashkortostan and adjacent territories.

Keywords: Syringa L.; flowering; duration; species; sort; decorativeness; beautifully flowering shrubs; phenological observations; seasonal development of plants; introduction; climate change; Ufa city; Botanical Garden.
\end{abstract}

УДК 581.524.1: 631.524.1

Статья поступила в редакцию 06.12.2017

\section{ВЛИЯНИЕ ДЕРЕВЬЕВ РОДА JUGLANS L. НА ЦЕЛЛЮЛОЗОРАЗРУШАЮЩУЮ АКТИВНОСТЬ ПОЧВЫ В УСЛОВИЯХ ДЕНДРАРИЯ БОТАНИЧЕСКОГО САДА САМАРСКОГО УНИВЕРСИТЕТА} (C) 2018

\author{
Помогайбин Ефим Александрович, аспирант кафедры экологии, ботаники и охраны природы \\ Помогайбин Александр Владимирович, кандидат биологических наук, \\ заместитель директора Ботанического сада \\ Самарский национальный исследовательский университет имени академика С.П. Королёва \\ (2. Самара, Российская Федерачия)
}

\begin{abstract}
Аннотация. Древесные растения качественно и количественно изменяют приток веществ в почвенную среду, перехватывая кроной осадки и насыщая их выделениями из листьев и материалом, осажденным из воздуха. Поступление наземной (листовой опад) и подземной (корневой отпад) мортмассы влияет на химические процессы в почве и способно изменять ее морфологическое строение. Образуя и высвобождая опад, деревья косвенно активизируют почвенную микрофлору. Орехоплодные растения, формирующие богатые белками и липидами семена, используются человеком начиная с глубокой древности как пищевые, лекарственные растения, источник биологически активных веществ. История интродукции орехов (Juglans) в Ботаническом саду Самарского университета начинается уже с момента создания сада. Наша работа представляет результаты оценки целлюлозолитической активности почвы под деревьями рода орех в дендрарии Ботанического сада Самарского университета.

Отбор проб почвы был выполнен в сентябре 2011 г. в подкроновом пространстве для деревьев орехов грецкого (J. regia) и черного (J. nirga) (у каждого вида - старого, среднего возраста, молодого экземпляров), орехов айлантолистного (J. ailanthifolia), маньчжурского (J. mandshurica), серого (J. cinerea), сердцевидного (J. cordiformis), скального (J. microcarpa), в качестве контроля использовали почву питомника Ботанического сада. Определение целлюлозоразрушающей активности выполняли аппликационным методом в чашках Петри. Визуальный осмотр проб экспонированной бумаги обнаружил ее достаточную сохранность в контроле и сильное разрушение под влиянием почвы в вариантах орех грецкий (старое дерево), орех черный (все варианты), орех скальный. На части полосок развилась пигментация, предположительно связанная с развитием различных групп микроорганизмов, то есть большинство деревьев орехов оказывали на микрофлору почвы оздоравливающее воздействие, подавляя фитопатогены. Слабее других данный эффект был выражен для орехов серого и скального. Почва питомника (контроль) показала целлюлозолитическую активность около $55 \%$, большинство проб из ризосферы орехов имело повышенный уровень активности (кроме ореха грецкого
\end{abstract}


молодого и ореха грецкого среднего возраста). Сравнение полученных результатов с данными 2009 г. показало, что целлюлозоразрушающая активность почвы изменяется по годам, испытывая влияние погодных условий.

Ключевые слова: древесные растения; влияние на почву; древесные интродуценты; орех грецкий; орех черный; орех айлантолистный; орех маньчжурский; орех серый; орех сердцевидный; орех скальный; Ботанический сад; биологическая активность почвы; аппликационный метод; целлюлозолитическая активность; влияние возраста и вида деревьев; влияние погодных условий.

\section{Введение}

Влияние деревьев на почву оказывается различными путями. Древесные растения качественно и количественно изменяют приток веществ в почвенную среду, перехватывая кроной осадки и насыщая их выделениями из листьев и материалом, осажденным из воздуха. Поступление наземной (листовой опад) и подземной (корневой отпад) мортмассы влияет на химические процессы в почве и способно изменять ее морфологическое строение. Образуя и высвобождая опад, деревья косвенно активизируют почвенную микрофлору [1], которая адаптируется к специфической морфологии и полифенольному составу специфического опада [2]. Переход части углерода из продуктов фотосинтеза в почву через корневые экссудаты также может сильно влиять на активность и структуру сообществ почвенных микроорганизмов, что на уровне экосистем выражается в изменении скорости цикла углерода [3]. Химический состав и физическая природа листьев, коры, ветвей и корней, доступность питательных веществ являются факторами, участвующими в регуляции активности микробиоты и почвенной фауны, вовлеченных в разложение растительных остатков [4]. Расщепление целлюлозы имеет огромное значение в круговороте углерода, так как в ее состав входит более 50\% всего органического углерода биосферы. На долю целлюлозы приходится 45-80\% сухого веса растений [5]. По химической природе целлюлоза - полисахарид, состоящий из цепочек глюкозы по 100-200 молекул. Это стойкое органическое соединение, разрушающееся только при действии очень сильных окислителей. В природных условиях разрушение целлюлозы осуществляется микроорганизмами, образующими ферменты целлюлазы [6; 7]. Различают аэробное и анаэробное расщепление целлюлозы. В аэробных условиях большая часть целлюлозы окисляется до углекислоты и воды, лишь незначительное ее количество окисляется не полностью и входит в состав гумуса. Основной вклад в процесс аэробного разложения целлюлозы принадлежит грибам (Fusarium, Botrytis и др.), в процессе участвуют также миксобактерии таких родов, как Cytophaga, Sporocytophaga, Myхососcus, Sorangium и Polyangium, и сходные с псевдомонадами бактерии рода Cellvibrio. В анаэробных условиях разложение клетчатки осуществляют мезофильные бактерии Bac. cellulosae omelianskii, некоторые кокки и термофильные клостридии. Некоторые из них могут развиваться только в присутствии в субстрате целлюлозы или целлобиозы. Процесс разложения протекает по типу брожения. Вначале под действием целлюлаз происходит внеклеточный гидролиз, продукты которого - глюкоза и целлобиоза затем сбраживаются с образованием уксусной, масляной, молочной и муравьиной кислот, углекислоты и молекулярного водорода. В смешанных культурах эти кислоты под действием метанобразующих бактерий подвергаются брожению, основным продуктом которого является метан [7].

Орехоплодные растения, формирующие богатые белками и липидами семена, используются человеком начиная с глубокой древности [8-11]. Помимо традиционного использования в качестве пищевых продуктов и высоколипидного растительного сырья, признанных лекарственных растений $[11 ; 12]$ они также служат хранилищем биологически активных веществ [13], что привлекает к ним интерес с позиций организации здорового питания населения [14].

История интродукции орехов в Ботаническом саду Самарского университета начинается уже с момента создания сада, основные посадки орехов провели еще до 1953 года. В общей сложности за период с 1936 по 2004 гг., согласно спискам в регистрационных журналах, были получены и высеяны около 500 образцов семян Ореховых: до 1960 г. - 113; до 1970 г. - 20; до 1980 г. - 26; до 1990 г. - 89; до 2000 г. - 149 и до 2005 г. - 96 образцов. Состав коллекции динамически изменяется, что зависит от поступления новых образцов, продолжительности их жизни, а также времени отпада. Динамика численности дендрологической коллекции орехов Самарского ботанического сада: 1950 г. - 3 вида, 1964 г. - 9 видов, 1973 г. 5 видов, 1992 г. 13 видов, 2004 г. - 7 видов, 17 форм и 2 гибрида [15-17].

Ранее были подробно изучены особенности их роста, фенологического развития, уровень устойчивости, начало изучение структурно-функциональных особенностей листьев [18]. Однако для древесных интродуцентов важным моментом является их воздействие на почвенную среду, которое может принимать формы почвоутомления. Наша работа, включающая изучение особенностей средопреобразующего влияния деревьев рода орех, продолжает и дополняет ранее выполненные исследования и представляет результаты оценки целлюлозолитической активности почвы под деревьями рода орех в дендрарии Ботанического сада Самарского университета.

\section{Условия и методы исследований}

Отбор проб почвы из слоя 0-10 см был выполнен в дендрарии Ботанического сада в сентябре 2011 г. в подкроновом пространстве (приблизительно в середине радиуса проекции кроны) для деревьев орехов грецкого и черного (у каждого вида - экземпляров старого, среднего возраста, молодого), а также деревьев орехов айлантолистного, маньчжурского, серого, сердцевидного, скального. В качестве контрольного образца использовали почву питомника Ботанического сада. Определение целлюлозоразрушающей активности выполняли чашечным аппликационным методом, для чего на дно чашек Петри помещали заранее взвешенные кусочки плотной белой бумаги, закрывали их капроном. Отвешивали на техниче- 
ских весах по 40 г почвы каждого образца, помещали на капрон и увлажняли до $60 \%$ от плотной влагоемкости. Чашки закрывали крышкой и ставили в термостат при температуре $27-28^{\circ} \mathrm{C}$ на 30 суток [7]. По окончании опыта остатки бумаги осторожно вынимали, тщательно освобождали от частичек почвы и взвешивали. По разнице в весе, выраженной в процентах от начального веса фильтровальной бумаги, судили о степени разложения клетчатки в почве.

\section{Результаты исследования и их обсуждение}

Визуальный осмотр проб бумаги, которую экспонировали в контакте с почвой, обнаружил довольно хорошую ее сохранность в контрольном варианте (почва питомника) и сильное разрушение под влиянием почвы в вариантах орех грецкий (старое дерево), орех черный (все варианты), орех скальный (рис. 1-3). На части бумажных полосок появилась хорошо заметная пигментация, которая предположительно была связана с развитием различных групп микроорганизмов. Как известно, полевое определение особенностей биологической активности почвы путем аппликации полосок бумаги рекомендуется даже садоводам-любителям, при этом характер пигментации образующихся колоний рассматривается в качестве важного диагностического признака $[19 ; 20]$.

Как правило, фитопатогенные грибы образуют на бумаге (ткани) колонии черной (стахиботрис), серой (альтернария), фиолетово-малиновой окраски (фузариум), распространяясь по всей поверхности пробы [19]. Напротив, если поверхность ткани или бумаги желтая, зеленая или розовая, это свидетельствует о благоприятном составе микрофлоры и здоровом состоянии почвы. Выявленные в наших экспериментах особенности пигментации бумаги показали появление заметных ярко-желтых пятен (орехи грецкий среднего возраста, черный среднего возраста и молодой, серый). Бледно-желтая окраска пятен появилась на бумаге под действием проб почвы из-под орехов маньчжурского, сердцевидного, айлантолистного, грецкого молодого и довольно слабо в варианте с почвой питомника (контроль). В то же время на бумаге, контактировавшей с почвой из-под орехов серого и скального, сформировались также отдельные пятна ярко-лиловой окраски, которые в литературе связывают с присутствием в почве фузариума [19; 20]. Это может означать, что большинство деревьев орехов оказывали на микрофлору почвы оздоравливающее воздействие, подавляя фитопатогены. Слабее других данный эффект был выражен в почве под орехами серым и скальным, где выявлялось некоторое присутствие фузариума. Особенности пигментации были зафиксированы нами на цифровых фото, но, к сожалению, возможности черно-белых иллюстраций не позволили их представить в данной статье.

В почве под орехом грецким с возрастом дерева увеличивалась целлюлозоразрушающая активность. Так, в пробе почвы из-под ореха грецкого молодого целлюлозоразрушающая активность была равна 53\%, ореха грецкого старого - 79\%. Для ореха черного пробы почвы из-под деревьев разного возраста показали достаточно близкую целлюлозоразрушающую активность (от 72\% до 78\%). Пробы почвы из-под орехов серого, маньчжурского, сердцевидного, айлантолистного обладали практически одинаковым уровнем целлюлозоразрушающей активности (от $69 \%$ до 72\%). Самая высокая целлюлозоразрушающая активность была в пробе почвы ореха скального $(82 \%)$. Контроль - почва питомника - показала целлюлозоразрушающую активность на уровне 55\%. Таким образом, большинство почвенных проб характеризовалось повышенной по сравнению с контролем целлюлозоразрушающей активностью (кроме ореха грецкого молодого и ореха грецкого среднего возраста).

Сравнение полученных результатов с данными проведенной нами в 2009 предварительной серии опытов показало, что целлюлозоразрушающая активность почвы изменяется по годам, испытывая влияние погодных условий (рис. 4). Так, в 2009 г. во всех почвенных пробах была отмечена способность разрушать целлюлозу. Под влиянием всех деревьев, кроме ореха грецкого молодого, разрушение целлюлозы шло слабее, чем в контрольном образце - почве питомника. Для ореха черного влияние возраста практически не было выражено, разрушение целлюлозы составило от 41 до 52\%. У ореха грецкого при увеличении возраста активность целлюлозолитических ферментов снижалась, уровень расщепления целлюлозы изменялся от 74 (молодой) до 26\% (старый орех).

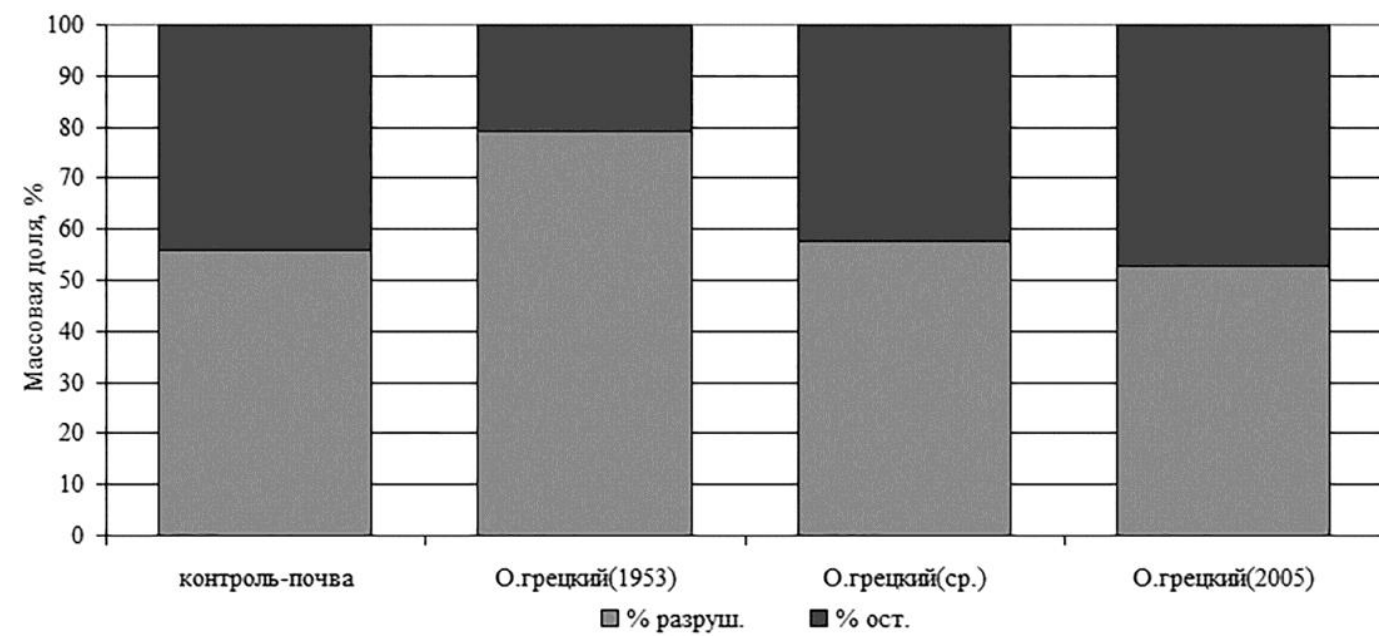

Рисунок 1 - Целлюлозоразрушающая активность проб почвы из-под деревьев ореха грецкого разного возраста 
Помогайбин Е.А., Помогайбин А.В.

Влияние деревьев рода Juglans L. на целлюлозоразрушающую активность почвы...

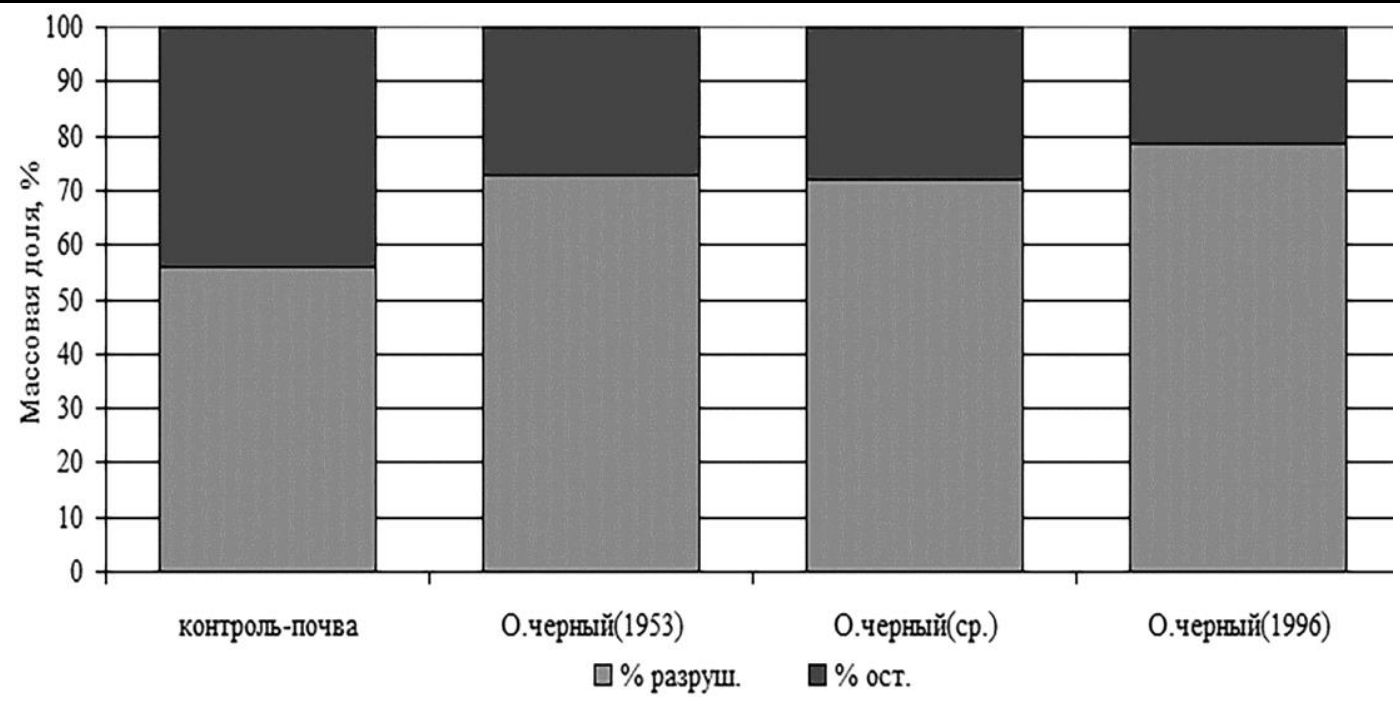

Рисунок 2 - Целлюлозоразрушающая активность проб почвы из-под деревьев ореха черного разного возраста

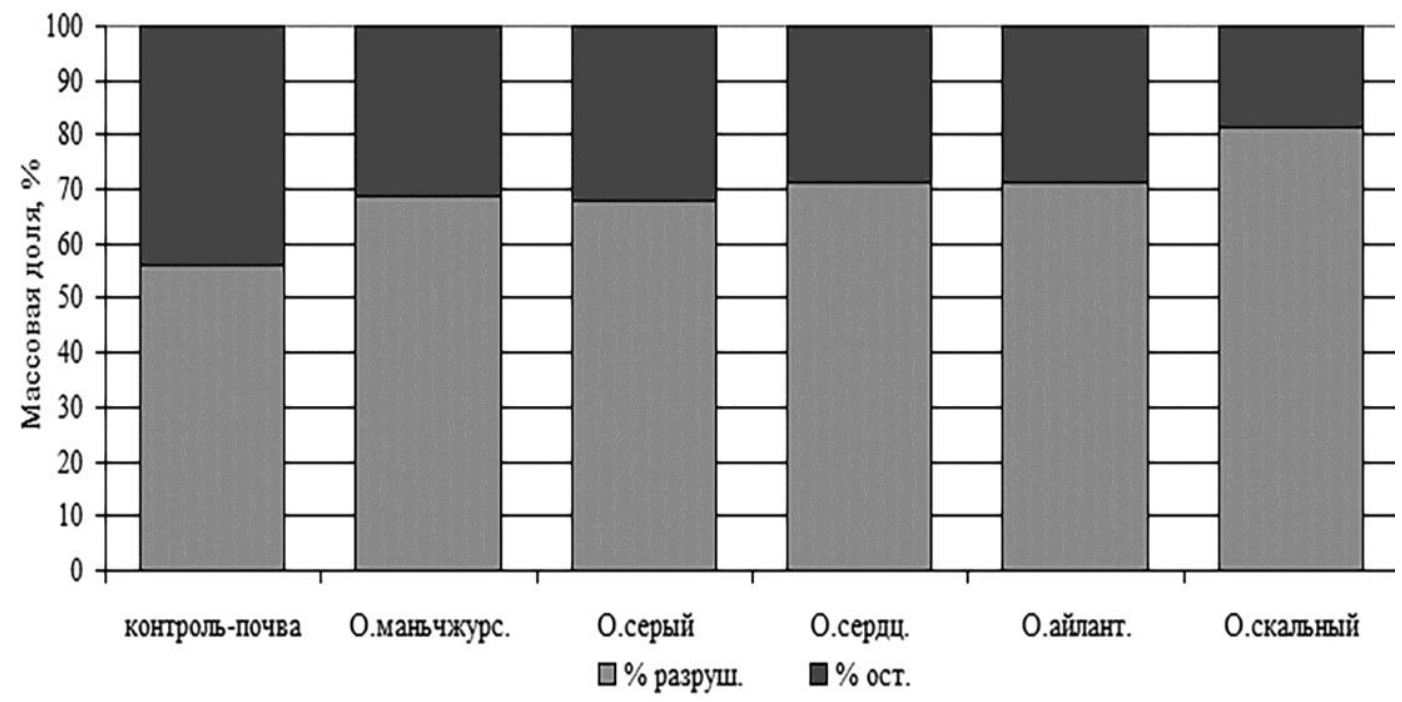

Рисунок 3 - Целлюлозоразрушающая активность проб почвы из-под деревьев орехов различных видов

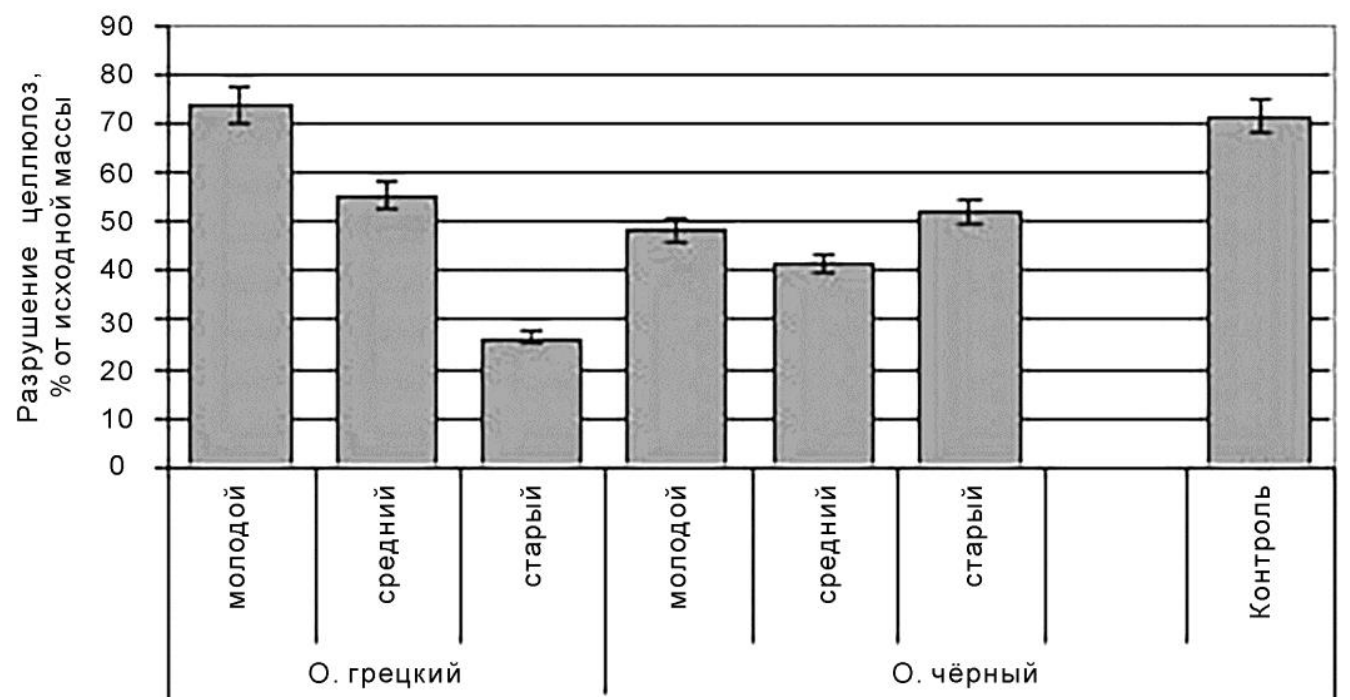

Рисунок 4 - Результаты оценки целлюлозоразрушающей активности проб почвы (2009 г.)

Эти данные представляют противоположную картину по сравнению с 2011 г. Возможно, причину изменений следует искать в колебаниях режима увлажнения в весенне-осенне-летний период. В частности, высокий уровень увлажнения почвы в 2011 г. мог вызвать активизацию микрофлоры, испытавшей в 2010 г. воздействие экстремальной засухи.

\section{Заключение}

Таким образом, в подкроновом пространстве деревьев рода орех в зависимости от видовой принадлежности и возраста экземпляра наблюдались разнонаправленные изменения целлюлозоразрушающей активности. Характер пигментации полосок бумаги указывал на изменение активности наиболее распро- 
страненных групп почвенной микробиоты, а именно: большинство деревьев орехов оказывали на микрофлору почвы оздоравливающее воздействие, подавляя фитопатогены. Слабее других данный эффект был выражен в почве под орехами серым и скальным, где пигментация бумаги указывала на некоторое присутствие фузариума.

\section{Список литературы:}

1. Ayres E., Dromph K.M., Bardgett R.D. Do plant species encourage soil biota that specialise in the rapid decomposition of their litter? // Soil Biology \& Biochemistry. 2006. Vol. 38. P. 183-186.

2. Hättenschwiler S., Vitousek P.M. The role of polyphenols in terrestrial ecosystem nutrient cycling // Trends in Ecology \& Evolution. 2000. Vol. 15. P. 238243.

3. Weber P., Bol R., Dixon L., Bardgett R.D. Large old trees influence patterns of delta C-13 and delta N-15 in forests // Rapid Communications in Mass Spectrometry. 2008. Vol. 22. P. 1627-1630.

4. Rhoades C.C. Single-tree influences on soil properties in agroforestry: lessons from natural forests and savanna ecosystems // Agroforestry Systems. 1996. Vol. 35. № 1. P. 71-94.

5. Гудвин Т., Мерсер Э. Введение в биохимию растений: В 2-х т. Т. 2. М.: Мир, 1986. 312 с.

6. Частухин В.Я., Николаевская М.А. Биологический распад и ресинтез органических веществ в природе. Л.: Наука, 1969. 326 с.

7. Колешко О.И. Экология микроорганизмов почвы: лабораторный практикум. Минск: Высш. школа, 1981. $176 \mathrm{c}$.

8. Алексеев Ю.А., Жмылев П.В., Карпухина Е.А. Деревья и кустарники. М.: 1997. 592 с.

9. Атлас растений. М.: ОЛМА-ПРЕСС Образование, 2005. 623 c.
10. Баранов В.Д., Устименко Г.В. Мир культурных растений. М.: Мысль, 1994. 381 с.

11. Prasad R.B.N. Walnuts and pecans // Encyclopedia of Food Sciences and Nutrition (Second Edition). Academic Press, 2003. P. 6071-6079.

12. Берзегова А.А. Химический состав плодов ореха грецкого // Новые технологии. 2007. № 4. C. 28-29.

13. Стрела Т.Е. Орех грецкий. К.: Наук. Думка, 1990. 192 c.

14. Poon T., Baldwin N. Authorised EU health claim for walnuts // Foods, Nutrients and Food Ingredients with Authorised EU Health Claims, 2014. P. 329-348.

15. Помогайбин А.В. Краткие итоги интродукции видов рода Juglans в Ботаническом саду Самарского госуниверситета // Самарская Лука: Бюллетень. 2007. T. 16, № 1-2 (19-20). C. 110-114.

16. Помогайбин А.В. Ритмы развития и зимостойкость орехов Самарского ботанического сада // Интродукция, акклиматизация, охрана и использование растений. Самара, 1991. С. 89-93.

17. Розно С.А., Кавеленова Л.М. Итоги интродукции древесных растений в лесостепи Среднего Поволжья. Самара: Издательство «Самарский университет», 2007. 228 с.

18. Помогайбин А.В. Эколого-биологический анализ результатов интродукционных испытаний видов рода opex (Juglans L.) в лесостепи Среднего Поволжья: автореф. дис. ... канд. биол. наук. Тольятти, 2008. 16 c.

19. Определение фитопатогенов в почве [Электронный ресурс] // http://dizayn-reya.narod.ru/3/3.htm.

20. Микробиологический анализ почвы [Электронный ресурс] // Сибирский клуб любителей дачной жизни. - http://sib-sad.info.

\section{JUGLANS L. GENUS TREES INFLUENCE ON CELLULOLYTIC SOIL ACTIVITY IN SAMARA UNIVERSITY BOTANICAL GARDEN DENDRARIUM}

(C) 2018

Pomogaybin Efim Alexandrovich, postgraduate student of Ecology, Botany and Nature Conservation Department

Pomogaybin Alexander Vladimirovich, candidate of biological sciences, deputy director of the Botany Garden Samara National Research University (Samara, Russian Federation)

Abstract. Woody plants change qualitatively and quantitatively the substances dynamics into the soil environment, acting on intercepting and saturating them with discharge from the leaves and material precipitated from the air. The arrival of the ground (leaf litter) and underground (root-slope) mort mass influences the chemical processes in the soil and its morphological structure changing. By forming and releasing litter, the trees indirectly activate the soil microflora. The nut plants, forming seeds rich in proteins and lipids, have been used by humans since ancient times as food, medicinal plants, a source of biologically active substances. The nuts (Juglans) introduction history in Samara University Botanical Garden begins from the moment of the garden creation. Our work presents the results of the evaluation of the cellulolytic activity of the soil under the walnut trees in Samara University Botanical Garden Dendrarium. The soil sampling were carried out in September 2011 in the sub-crown space for the trees of J. regia and J. nirga (for each species - old, middle age, young specimens), other Juglans species (J. ailanthifolia, J. mandshurica, J. cinerea, J. cordiformis, J. microcarpa) were also tested. The determination of cellulolytic activity was carried out by the application method in Petri dishes. Visual examination of exposed paper samples showed its sufficient safety in the control and strong destruction under the influence of the soil in variants J. regia (old tree), J. nirga (all variants), J. regia. A comparison of the results obtained with the data of 2009 showed that the cellulolytic activity of the soil varies from year to year, under the influence of weather conditions.

Keywords: woody plants; influence on soil; woody introducers; J. regia; J. nirga; J. ailanthifolia; J. mandshurica; J. cinerea; J. cordiformis; J. microcarpa; Botanical Garden; biological soil activity; application method; cellulolytic activity; influence of age and type of trees; influence of weather conditions. 